\title{
Economic Analysis of Fish Drying in Junput Khuti of West Bengal
}

\author{
Soumyadip Purkait ${ }^{1}$, Somen Sahu ${ }^{1 *}$, Bostanul Arefin ${ }^{1}$, Subir Kumar Pradhan ${ }^{1}$, \\ Anisha Sharma ${ }^{1}$, Satyanarayan Boda ${ }^{1}$, Sutanu Karmakar ${ }^{2}$ and Saymantaka Sahu ${ }^{3}$ \\ ${ }^{1}$ Department of Fishery Economics \& Statistics, Faculty of Fishery Sciences, West Bengal \\ University of Animal and Fishery Sciences, Kolkata-700094, India \\ ${ }^{2}$ Aquatic Environment \& Health Management Division, ICAR-Central Institute of Fisheries \\ Education, Mumbai-400061, India \\ ${ }^{3}$ Departmentof Zoology, City College, University of Calcutta, Kolkata- 700009, India
}

*Corresponding author

\begin{tabular}{|l|}
\hline K e y w or d s \\
$\begin{array}{l}\text { Dry fish, Economicst and } \\
\text { point, Sustainable } \\
\text { development }\end{array}$ \\
\hline Article Info \\
\hline $\begin{array}{l}\text { Accepted: } \\
\text { 24 September } 2018 \\
\text { Available Online: } \\
\text { 10 October } 2018\end{array}$ \\
\hline
\end{tabular}

A B S T R A C T

For a social and economic standpoint fish drying will remain an important part of the rural economy. The present investigation was conducted to find out the economics of Junput khuti in coastal belt of West Bengal. The survey was done from September 2017 to April 2018. The study area was purposively selected and the total economics involved in this system was analyzed. Survey question schedule was made for the collection of data. Several species of coastal and marine fish like Harpodon nehereus, Trichiurus savala, Prawns and crabs, Sardinella longiceps, Chirocentrus dorab, Polynemus indicus, Rastraliger kanagurta, Pama pama, Leognathus sp., Setipina phasa, Arius sp, Escualosa thoracata and Polynemus paradiseus etc were commonly used for drying. Different types of businessmen are involved in the trading system like fish processor, Beparis, Aratdars, Wholesalers, Retailers and exporters etc. The price of dried marine fish varies with the size, seasonal availability and quality of the fish species. The study revealed that the dry fish industry can made it a major contributor in earning foreign exchange and at the same time play a crucial role to the employment generation and socio-economic upliftment of a major portion of coastal rural fisher folk.

\section{Introduction}

Dry fishes are value-added products of lowcost marine fishes with increased shelf-life of the perishable fishes for longer storage. Among the world, India is the second fish producing country and contribute $5.43 \%$ in global fish production. In relations to nutritional quality of fish, sometimes dry fish show higher quality standards than of fresh fish (Payra et al., 2016). In India, consumption of dried fishes is about $32 \%$ of the total marine landings and about $17 \%$ of the total catch used for the production of dry fishes (Shakila et al., 2003).

In drying, salt is used to remove the nonhalophilic, spore-forming bacteria and osmophilic fungi (Sivaraman et al., 2015). Dry fish is an essential source of animal protein supplement, which is preferred as a keydish or used as a flavouring agent in 
combination with other food items. However, all dry fish are in great demand during the fishing ban period when the availability of fresh fish in the market is lower (Das et al., 2013).

Fish is an essential component of the daily diet, and the dried fish is a vital source of protein in India and especially in West Bengal. Being a state of rivers, bells and reservoirs with a high potential of aquatic resources, fisheries of West Bengal play an important role in the employment generation of rural coastal people. The state has 3 coastal districts. They are East Midnapore, South 24 Parganas, North 24 Parganas. Essential landing centres are Diamond Harbour, Kakdweep, Namkhana, Digha, Sankarpur etc. The state has many landing centres and fishing villages along the coast. About $61 \%$ of the total landings are taken in the fresh condition, and the remaining part is utilised by various fishery industries. The coastal people of these districts are engaged in fish curing/drying activities. In West Bengal where fish landing, as well as drying activity, is undertaken is known as Khuti (Samanta et al., 2016). In Khutis fishes are dried under natural sunlight in bamboo poles in the coastal areas. The major Khuties located a coastal West Bengal includes Digha mohana, Sankarpur, Jaldha, Junput, Mandarmoni, Petuaghat etc. (Payra et al., 2016). These khuties have produced 10152 tons dry fish during 2015-16 (GoWB, 2016).

\section{Materials and Methods}

\section{Sampling frame}

To assess the economics of fish drying of Junput khuti of Deshapran CD Blockfrom Contai sub-division was purposively selected as representative from the district of Purba Medinipur. A list of 150 families connected with fish drying who are living in the surrounding area of the selected Khutis were prepared, and ten Khuti owners and dry fish processors were randomly selected for questionnaire and interview. Similarly, two auctioneers, two wholesalers and two retailers were also randomly selected for marketing analysis through interview and questionnaires.

\section{Questionnaires and data collection}

The questionnaire was developed in a logical sequence of that the target group could answer chronologically. For this study, a combination of the questionnaire, interview, Participatory Rural Appraisal (PRA) tool such as Focus Group Discussion (FGD) and cross-check interviews with key informants were used.

\section{Data collection}

Secondary data were collected from the available sources. Primary data were collected in 2017-18 using pre-tested structured questionnaires and interview in the local language and subsequently converted to English. Collected data were suitably categorized, tabulated for interpretations, generalizations and implications.

\section{Analysis of data}

The collected data were statistically analyzed using the statistical package SPSS 20.0 computer program (SPSS Inc. Chicago, Illinois, USA). Microsoft Excel was used for the representation of data and results. To estimate the various cost and income (Salim and Biradar, 2011) and to obtain profitability measures (Dhondyal, 1998) available standard procedures were followed.

\section{Results and Discussion}

\section{Capital cost}

In table 2, when considering correlations of the capital cost of farms in Junput Khuti, it is 
seen that there is significant (1\% level) high positive correlation between Construction of cemented tank and total capital cost.

\section{Model 1: Revealed with stepwise method of regression}

Total capital cost $=0.124+0.999 X$ construction of cemented tank+ construction of Bamboo rack+ $0.999 \times$ Land and farm equipment +0.999 X Miscellaneous

The equation clearly indicates that the most important variables (average value calculated for 1 bigha, in all the cases) are the cost of Construction of cemented tank, construction of bamboo rack, Land and farm equipment and Miscellaneous which showed positive impact upon capital cost.

By observing adjusted $\mathrm{R}^{2}$ value, it can be concluded that both parameters explain $100 \%$ variability in total capital cost.

\section{Variable cost}

A variable cost is a corporate expense that changes in proportion with production output. Variable costs increase or decrease depending on a company's production volume; they rise as production increases and fall as production decreases.

Variable costs are costs that change in proportion to the good or service that a business produces. Variable cost includes raw fish price, salt price, transportation cost, temporary shed, electricity charges, labour charges and miscellaneous.

The analysis depicted the variable cost value (unit: 1 bigha) for the raw fish price, salt price, transportation cost, cost of temporary shed, electricity charges, labour charge and the miscellaneous cost was Rs. $1283616 \pm$ 752400, Rs. $50495 \pm 5139$, Rs. $48835 \pm 5939$,
Rs. $25265 \pm 4302$, Rs. $5536 \pm 1043$, Rs. 97966 \pm 18826 and Rs. $8017 \pm 1467$ respectively. The total variable cost was Rs. $1207427 \pm$ 207571.

In table 3, when considering correlations of variable cost of farms in Junput Khuti, it is seen that there is significant ( $1 \%$ level $)$ moderate positive correlation between raw fish price and salt price, significant (5\%) moderate positive correlation between raw fish price and temporary shed, significant (1\%) high positive correlation between raw fish price and labour charge, significant (1\%) high positive correlation between raw fish price and total variable cost. It was also seen that a significant ( $1 \%$ level) moderate positive correlation between salt price and transportation cost, significant (1\%) high positive correlation between salt price and temporary shed, significant $(5 \%)$ moderate positive correlation between salt price and labour charge, significant (1\%) high positive correlation between salt price and total variable cost. Further, it was seen that there is significant $(5 \%$ level $)$ moderate positive correlation between transportation cost and temporary shed, significant (1\% level) high positive correlation between transportation cost and labour charge, significant (5\% level) moderate positive correlation between transportation cost and total variable cost. Table 4 also depicted that a significant (5\% level) moderate positive correlation between temporary shed and electricity charge, significant $(5 \%$ level $)$ moderate positive correlation between temporary shed and labour, significant (5\% level) moderate positive correlation between the temporary shed and total variable cost. In case of electricity charge, it was seen that there was a significant $(5 \%)$ moderate positive correlation with labour charge. It was also seen that between labour charge and total variable cost there was also a significant $(5 \%)$ high positive correlation (Fig. 1 and 2; Table 1). 
Questionnaires and Data Collection

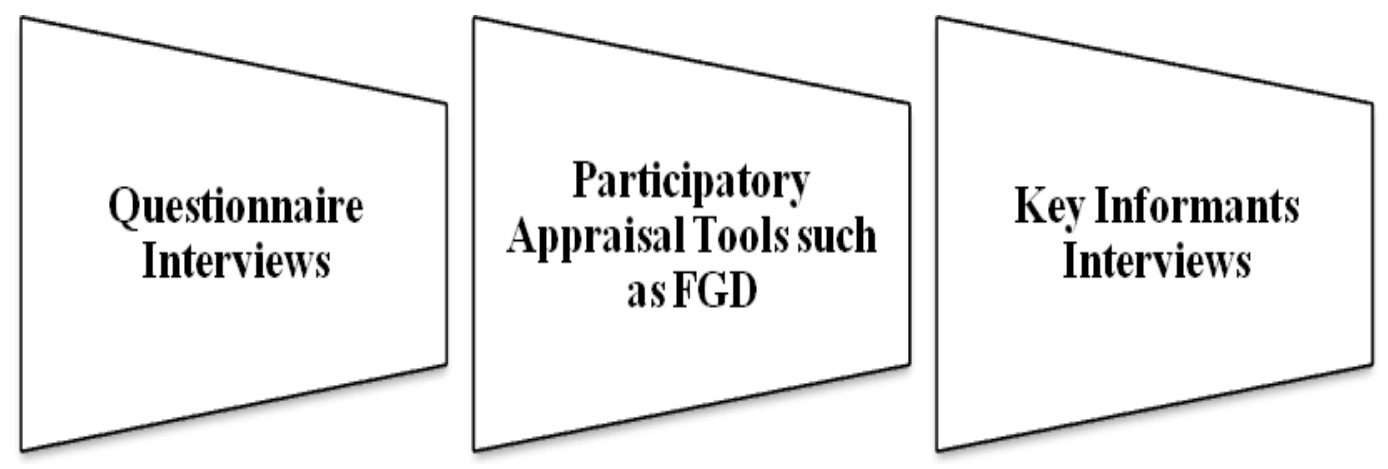

Fig.1 Capital cost of Junput Khuti

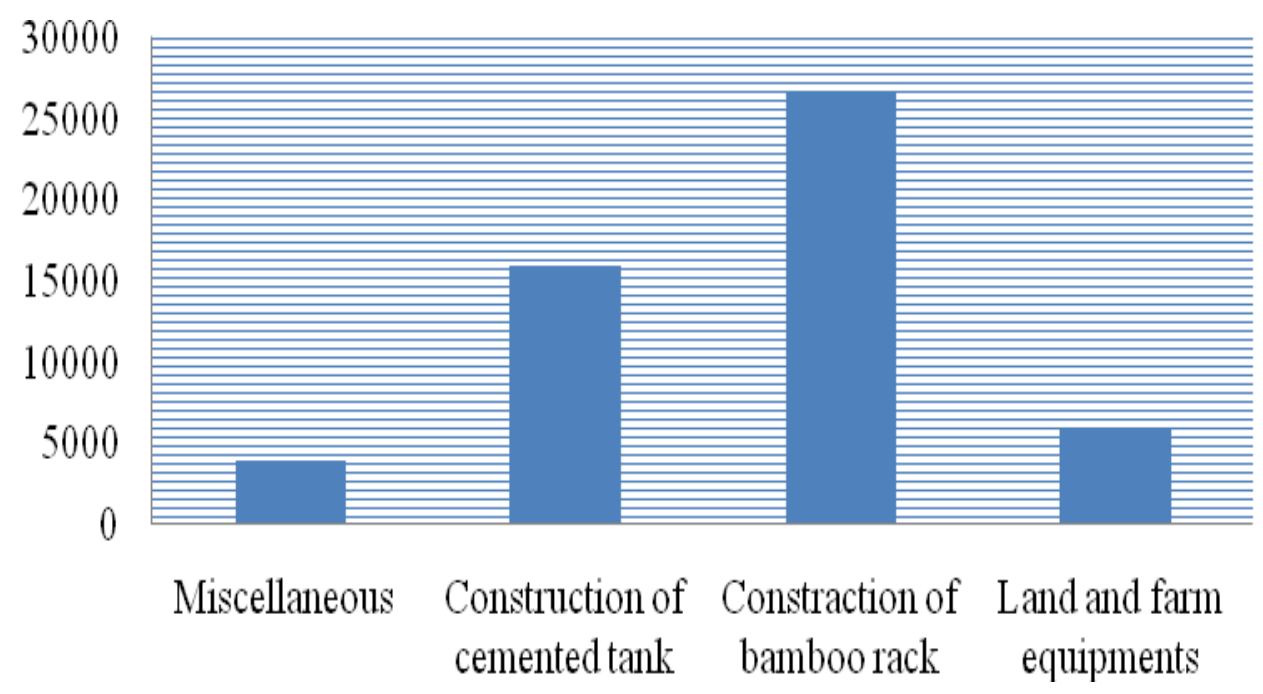

Fig.2 Variable cost of Junput khuti

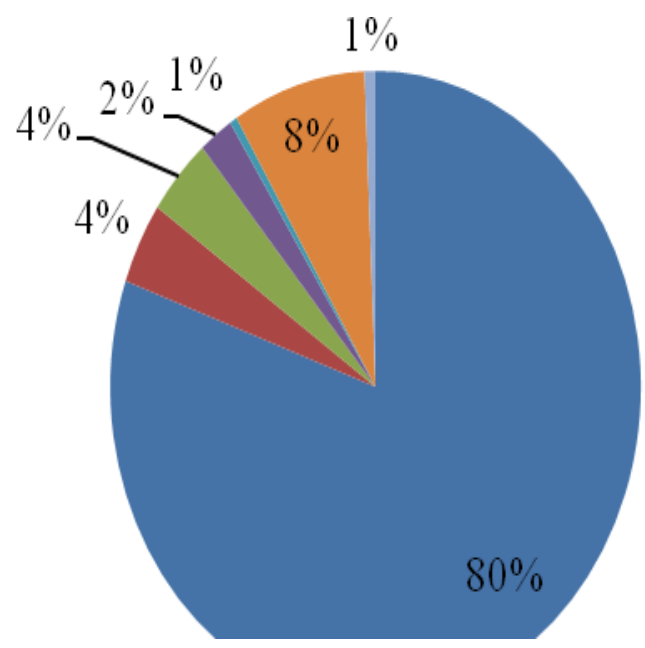

- Raw fish price

- Salt price

- Tranportation cost

- Tempurary shed

Electricity charges

- Labour charges

- Miscellaneous 
Table.1 Average economics of Junput khuti and their ratio analysis (Unit: Rs.)

\begin{tabular}{|l|l|}
\hline Particulars & Junput \\
\hline Area of Khuti (bigha) & 1 \\
\hline area of farm (Sq. metres) & 1337.8 \\
\hline Construction of cemented tank & 15901 \\
\hline Construction of bamboo rack & 26751 \\
\hline Land and farm equipment & 5875 \\
\hline Miscellaneous & 3894 \\
\hline Total capital cost & $\mathbf{5 2 4 2 1}$ \\
\hline Raw fish price & 971313 \\
\hline Salt price & 50495 \\
\hline Transportations cost & 48835 \\
\hline Temporary shed & 25266 \\
\hline Electricity charges & 5536 \\
\hline Labour charges & 97966 \\
\hline Miscellaneous & 8017 \\
\hline Total variable cost & $\mathbf{1 2 0 7 4 2 8}$ \\
\hline Depreciation on capital cost @ 10\% & 5242.09 \\
\hline Interest on capital cost @ 11\% & 4765.54 \\
\hline Interest on variable cost @ 11\% & 109766.18 \\
\hline Total fixed cost & $\mathbf{1 1 9 7 7 4}$ \\
\hline Total cost & 1327202 \\
\hline Total dry fish produce (5 months) & 13490 \\
\hline Average price & 110 \\
\hline Gross revenue & $\mathbf{1 7 5 8 2 2 7}$ \\
\hline Net revenue & $\mathbf{4 3 1 0 2 5}$ \\
\hline Operating Ratio (OR) & $\mathbf{6 8 . 6 7 \%}$ \\
\hline Fixed Ratio (FR) & $\mathbf{6 . 8 1 \%}$ \\
\hline Gross Ratio (GR) & $\mathbf{7 5 . 4 9 \%}$ \\
\hline Net operating income & $\mathbf{5 5 0 7 9 9}$ \\
\hline Net profit & $\mathbf{4 3 1 0 2 5}$ \\
\hline Input output ratio & $\mathbf{0 . 6 3}$ \\
\hline Profitability ratio & $\mathbf{0 . 3 6}$ \\
\hline Net profit ratio & $\mathbf{0 . 2 5}$ \\
\hline Productivity Index & $\mathbf{1 3 2 \%}$ \\
\hline Per kg. production price & $\mathbf{9 8 . 3 8}$ \\
\hline & \\
\hline
\end{tabular}


Table.2 Correlation matrix for average economics (unit 1 bigha) in connection with capital cost of dry fish industry considering all the involved parameters in Junput khuti

\begin{tabular}{|c|c|c|c|c|c|}
\hline & $\begin{array}{l}\text { Construction of } \\
\text { cemented tank }\end{array}$ & $\begin{array}{l}\text { Construction of } \\
\text { bamboo rack }\end{array}$ & $\begin{array}{l}\text { Land and farm } \\
\text { equipment }\end{array}$ & Miscellaneous & $\begin{array}{c}\text { Total capital } \\
\text { cost }\end{array}$ \\
\hline Construction of cemented tank & 1.000 & & & & \\
\hline Construction of bamboo rack & -0.515 & 1.000 & & & \\
\hline Land and farm equipment & -0.172 & 0.095 & 1.000 & & \\
\hline Miscellaneous & -0.285 & 0.457 & 0.315 & 1.000 & \\
\hline Total capital cost & $0.946 * *$ & -0.230 & -0.057 & -0.091 & 1.000 \\
\hline
\end{tabular}

Table.3 Correlation matrix for average economics (unit 1 bigha) in connection with variable cost of dry fish industry considering all the involved parameters in Junput khuti

\begin{tabular}{|c|c|c|c|c|c|c|c|c|}
\hline & Raw fish price & $\begin{array}{l}\text { Salt } \\
\text { price }\end{array}$ & $\begin{array}{c}\text { Transportation } \\
\text { cost }\end{array}$ & $\begin{array}{c}\text { Temporary } \\
\text { shed }\end{array}$ & $\begin{array}{l}\text { Electricity } \\
\text { charges }\end{array}$ & $\begin{array}{l}\text { Labour } \\
\text { charges }\end{array}$ & Miscellaneous & $\begin{array}{c}\text { Total } \\
\text { variable cost }\end{array}$ \\
\hline Raw fish price & 1.000 & & & & & & & \\
\hline Salt price & $.776^{* *}$ & 1.000 & & & & & & \\
\hline Transportation cost & 0.614 & $.782^{* *}$ & 1.000 & & & & & \\
\hline Temporary shed & $.705^{*}$ & $.869^{* *}$ & $.745^{*}$ & 1.000 & & & & \\
\hline Electricity charges & 0.476 & 0.540 & 0.591 & $.723^{*}$ & 1.000 & & & \\
\hline Labour charges & $.809^{* *}$ & $.660^{*}$ & $.829^{* *}$ & $.661^{*}$ & $.715^{*}$ & 1.000 & & \\
\hline Miscellaneous & 0.366 & 0.335 & 0.504 & 0.555 & 0.439 & 0.381 & 1.000 & \\
\hline Total variable cost & $.996^{* *}$ & $.802^{* *}$ & $.677^{*}$ & $.741^{*}$ & 0.530 & $.852^{* *}$ & 0.395 & 1.000 \\
\hline \multicolumn{9}{|c|}{$* *$. Correlation is significant at the 0.01 level (2-tailed). } \\
\hline \multicolumn{9}{|c|}{ *. Correlation is significant at the 0.05 level (2-tailed). } \\
\hline \multicolumn{9}{|l|}{ c. List wise $\mathbf{N}=10$} \\
\hline
\end{tabular}


Table.4 Correlation Matrix for Average Economics (unit 1 bigha) in connection with Fixed Cost of dry fish industry considering all the involved parameters in Junput khuti

\begin{tabular}{|c|c|c|c|c|}
\hline & $\begin{array}{l}\text { Depreciation on } \\
\text { capital cost @ 10\% }\end{array}$ & $\begin{array}{l}\text { Interest on capital } \\
\text { cost @ } 11 \%\end{array}$ & $\begin{array}{l}\text { Interest on variable cost @ } \\
11 \%\end{array}$ & $\begin{array}{l}\text { Total fixed } \\
\text { cost }\end{array}$ \\
\hline $\begin{array}{l}\text { Depreciation on capital cost } \\
\text { @ } 10 \%\end{array}$ & 1.000 & & & \\
\hline $\begin{array}{l}\text { Interest on capital cost @ } \\
11 \%\end{array}$ & $1.000^{* *}$ & 1.000 & & \\
\hline $\begin{array}{l}\text { Interest on variable cost @ } \\
11 \%\end{array}$ & -0.120 & -0.120 & 1.000 & \\
\hline Total fixed cost & 0.028 & 0.028 & $.989^{* *}$ & 1.000 \\
\hline \multicolumn{5}{|c|}{ **. Correlation is significant at the 0.01 level (2-tailed). } \\
\hline \multicolumn{5}{|l|}{ b. Listwise $\mathrm{N}=10$} \\
\hline
\end{tabular}


Model 1: Revealed with the stepwise method of regression

Total Variable Cost (T.V.C) $=4559.19+$ $1.031 X$ Raw fish price $+1.993 X$ Transportation cost $+3.416 \times$ Electricity charges $+0.616 X$ Labour charges $+0.964 X$ Temporary shed

The equation clearly indicates that the most important variables (average value calculated for 1 bigha, in all the cases) are raw fish price, transportation cost, electricity charges, labour charges and temporary shed which showed positive impact upon variable cost. By observing adjusted $\mathrm{R}^{2}$ value, it can be concluded that both parameters explain 100\% variability in total variable cost.

\section{Fixed costs}

The fixed cost for Khuties includes depreciation on fixed costs (@10\%), interest on capital costs (@ 11\%) and interest on variable costs (@11\%). The values were Rs. $5242 \pm 1460$, Rs. 4765 \pm 1328 and Rs. $109766 \pm 18870$ respectively and the total fixed cost was Rs. $105130 \pm 15686$.

\section{Model Revealed with stepwise method of regression}

Total fixed costs $($ TFC $)=0.0866+0.999 x$ interest on variable costs +1.909 depreciation on capital costs

It is seen that there is a significantly high correlation (1\%) between interest on capital costs and depreciation on capital costs and interest on variable costs and total fixed costs in table 4 . The equation clearly indicates that the most important variables (average value calculated for 1 bigha in all the cases) interest on variable costs and depreciation on capital costs which showed positive impact upon Total fixed costs. By observing adjusted $\mathrm{R}^{2}$ value, it can be concluded that electric both parameters explain $100 \%$ variability in total fixed cost.

Shifting from an underdeveloped sector towards a promising sector, first of all, it requires the attention of the government towards both the fishery and fishers related to the industry. In case of fishery it requires a sustainable policy starting from the procurement of fishes, up-gradation of the process maintaining the hygiene and the quality of the product through branding along with an appropriate marketing opportunity free from intervention of the middleman. Credit facility side-a-side insurance schemes may be incorporated to safeguard the fishers. As women's participation had the lion's share of the process, different measures related to health, education of the children, sanitary condition, safe and quality accommodation is of utmost importance towards the growth of the industry. With a synergistic effect of the above clauses obviously, make a turn of the industry towards the prosperity of both the industry and its allied community in near future meeting up the protein security of the underprivileged humanity of the country.

\section{References}

Das, M., Prathibha R., Maheswarudu G., Dash B. and Ramana P.V. (2013). An overview of dry fish landings and trade at Visakhapatnam Fishing Harbour. Regional Centre of CMFRI, Visakhapatnam. In: Marine Fisheries Information Service T\&E Ser., 215: 3-7.

Dhondyal, S.P. (1989). "Farm prices and farm profit". In: Farm Management Friend's Publication, Meerut, pp. 277-302.

GoWB (2016). Hand Book of Fisheries Statistics 2015-16, Department of Fisheries, Govt. of West Bengal.

Payra P., Maity R., Maity S. and Mandal B. (2016). Production and marketing of dry 
fish through the traditional practices in West Bengal coast: Problems and prospect. International Journal of Fisheries and Aquatic Studies, 4(6): 118-123.

Salim, S. S. and Biradar, R. S. (2001). In: Practical Manual on Fisheries Project Formulation and Management, CIFE Publication, pp. 26-28

Samanta, C., Bhaumik, U. and Patra, B.C. (2016). International Journal of Current Research and Academic Review. International Journal of
Current Research and Academic Review, 4(5): 84-100.

Shakila, R. J., Vijayalakshmi, K. and Jeyasekaran, G. (2003). Changes in histamine and volatile amines in six commercially important species of fish of the Thoothukkudi coast of Tamil Nadu, India stored at ambient temperature. Food Chemistry, 82(3): 347-352.

Sivaraman G.K., Visnuvinayagam S. and Jha A.K. (2015). Microbiological spoilage of dried fishes. Indian Council of Agricultureal Research. New Delhi.

\section{How to cite this article:}

Soumyadip Purkait, Somen Sahu, Bostanul Arefin, Subir Kumar Pradhan, Anisha Sharma, Satyanarayan Boda, Sutanu Karmakar and Saymantaka Sahu. 2018. Economic Analysis of Fish Drying in Junput Khuti of West Bengal. Int.J.Curr.Microbiol.App.Sci. 7(10): 3471-3479. doi: https://doi.org/10.20546/ijcmas.2018.710.402 